\title{
Detection of Aeromonas salmonicida Antigen in Diseased Fish Tissue
}

\author{
By D. H. MCCARTHY \\ Ministry of Agriculture, Fisheries and Food, Fish Diseases Laboratory, \\ The Nothe, Weymouth, Dorset
}

(Received 30 December I974; revised Io February 1975)

\section{INTRODUCTION}

Aeromonas salmonicida is the causative organism of fish furunculosis, a serious communicable disease affecting primarily Salmonidae and notifiable under the United Kingdom Diseases of Fish Act, I937. Unfortunately, because of similar pathologies it is impossible to differentiate unequivocally by clinical signs alone between furunculosis and other fish diseases caused by Gram-negative bacteria. In practice, however, a provisional diagnosis is made and treatment started, confirmation being delayed until sufficient growth for identification (usually 3 to 4 days) of the isolate has occurred on primary culture-media. Although a recently introduced method (McCarthy \& Rawle, 1975) has reduced this delay to $24 \mathrm{~h}$ by permitting serological identification of both scanty and impure growths of $A$. salmonicida, a requirement for rapid diagnosis still exists, both because furunculosis is a notifiable disease and because the increasing drug resistance of $A$. salmonicida makes specific therapy essential.

A technique is described for laboratory diagnosis of furunculosis in less than $2 \mathrm{~h}$ by detection of $A$. salmonicida antigen in fish tissue extracts using specific globulin-coated latex particles.

\section{METHODS}

Specific globulin. Globulins were precipitated from a hyper-immune (titre I :500) A. salmonicida strain 26 rabbit antiserum (McCarthy \& Rawle, 1975), as follows: $20 \mathrm{ml}$ of saturated ammonium sulphate $\left(76 \mathrm{~g} / 100 \mathrm{ml} \mathrm{H}_{2} \mathrm{O}\right.$ at $\left.20^{\circ} \mathrm{C}\right)$ were slowly stirred into an equal volume of antiserum, and precipitated globulins were sedimented at $2000 \mathrm{~g}$ for $15 \mathrm{~min}$ at $20{ }^{\circ} \mathrm{C}$, re-dissolved in $5 \mathrm{ml}$ of $0.9 \% \mathrm{NaCl}$ and then dialysed overnight at $4{ }^{\circ} \mathrm{C}$ against three 21 changes of $0.9 \% \mathrm{NaCl}$. Finally, suspended material was sedimented by centrifugation and the supernatant (globulin solution) stored at $-20^{\circ} \mathrm{C}$.

Latex sensitization. The optimum dilution of globulin solution for sensitizing latex particles $(0.8 \mathrm{I}$, Difco) was found by titrating doubling dilutions ( $\mathrm{I}: \mathrm{IO}$ to $\mathrm{I}: 320)$ in glycinebuffered saline (GBS; $7 \cdot 3 \mathrm{~g}$ glycine and $10 \mathrm{~g} \mathrm{NaCl}$ dissolved in $900 \mathrm{ml}$ water, adjusted to $\mathrm{pH} 8 \cdot 2$ with $\mathrm{NaOH}$ and then made up to I 1 with water) as follows: equal volumes ( $100 \mu \mathrm{l})$ of each globulin dilution and undiluted latex particles were mixed, shaken and incubated at $37{ }^{\circ} \mathrm{C}$ for $2 \mathrm{~h}$, then diluted with a further 2 vols. of GBS. The optimum globulin dilution was taken as that which produced the strongest agglutination under test conditions (see below) with a fish serum containing a low concentration of $A$. salmonicida antigen. Sensitized latex particles stored in the dark at $4{ }^{\circ} \mathrm{C}$ remained reactive for at least 6 months.

Extraction of antigen from fish tissue. The richest source of $A$. salmonicida antigen was 
found in necrotic muscle lesions or 'furuncles' which are easily visible as large 'boils' on most individuals in a diseased population; if 'furuncles' were absent, kidneys were extracted.

Approximately $5 \mathrm{ml}$ of the semi-solid furuncle material were removed by means of a Volkmann's bone scoop or similar instrument, blended with an equal volume of $0.9 \%$ $\mathrm{NaCl}$ in a macerator (Silverson Machines Ltd, London), then further diluted with 2 to 3 times its volume of $0.9 \% \mathrm{NaCl}$, vigorously shaken, and fish tissue sedimented at $20 \mathrm{~g}$ for Io min. The resulting supernatant was removed and centrifuged at $2500 \mathrm{~g}$ for $30 \mathrm{~min}$ to sediment bacteria. The deposit was re-suspended in an equal volume of $0.9 \% \mathrm{NaCl}$ adjusted to $\mathrm{pH}$ I I 0 with $\mathrm{NaOH}$, mixed and, if necessary, dispersed with a Pasteur pipette and boiled for $30 \mathrm{~min}$. Finally, suspended material was sedimented by centrifugation and the supernatant (soluble $A$. salmonicida antigen) stored at $-20{ }^{\circ} \mathrm{C}$.

A serious problem encountered in fish pathology is that diseased fish are often received in a condition precluding bacteriological examination, being either in a state of advanced autolysis, deep frozen, or occasionally immersed in fixative. To test whether the present method might be used with such materials, antigen was extracted from diseased fish after storage as follows: in $10 \%$ buffered formal saline for $24 \mathrm{~h}$; at $5{ }^{\circ} \mathrm{C}$ for 7 days; at $-20^{\circ} \mathrm{C}$ for 14 days.

Latex test. A $200 \mu \mathrm{l}$ portion of each antigen preparation, previously diluted $\mathrm{I}: 2 ; \mathrm{I}:$ Io or I : 100 with GBS containing I \% Tween 80 (Sigma), was mixed with I00 $\mu 1$ of sensitized latex suspension on a clean glass plate, shaken on a rotary mixer (Luckham Ltd, London) at I $50 \mathrm{rev} . / \mathrm{min}$ for $2 \mathrm{~min}$, and agglutination read with the naked eye. Controls consisted of I vol. test antigen and I vol. unsensitized latex, or I vol. A. salmonicida-free tissue extract and I vol. sensitized latex.

Latex sensitivity. Sensitivity of the method was assessed by testing extracts of healthy fish tissue incorporating varying amounts of two $A$. salmonicida antigens: intact bacteria, and lipopolysaccharide (LPS) extracted by the hot phenol method (Westphal, Lüderitz \& Bister, 1952).

Latex test specificity. Although the antiserum used in the present study was known to be non-reactive with six representative strains of each of the following Gram-negative fish pathogens: Aeromonas hydrophila, Vibrio anguillarum and Pseudomonas fuorescens (McCarthy \& Rawle, 1975), tissues from rainbow trout (Salmo gairdneri Richardson), killed with a minimum lethal dose of each organism, were extracted and tested.

\section{RESULTS AND DISCUSSION}

All the tissue extracts examined from fish with furunculosis, both naturally-occurring and experimentally-induced, reacted strongly in the latex test with titres of $I: I 00$ to I : 4000 for 'furuncle' material and I : Io to I : 80 for kidney. Moreover, extracts from healthy fish and those injected with other fish-pathogenic bacteria proved negative.

In addition to permitting rapid and accurate diagnosis of furunculosis, this method also allowed a positive diagnosis to be made from fish unsuitable for bacterial culture, for the titres were not significantly lower from fish stored at $-20{ }^{\circ} \mathrm{C}$ for $\mathrm{i} 4$ days or at $5{ }^{\circ} \mathrm{C}$ for 7 days. Furthermore, although titres of extracts from formal-fixed material (extracted after washing in tap water for $30 \mathrm{~min}$ ) were lower, a positive reaction was still obtained.

The sensitivity of the method (per $\mathrm{ml}$ tissue extract) was found to be: intact bacteria $\mathrm{I} \times 10^{4}$, and LPS $0.009 \mu \mathrm{g}$. The heat-stable antigens detected by the present method were probably LPS, since latex particles sensitized with globulin solution which had previously 
been absorbed with sheep red cells coated with $A$. salmonicida LPS failed to react even with high titre tissue extracts.

During development of the method, strong non-specific agglutination of sensitized latex particles by the high lipid content of fish tissue was successfully prevented, without a significant decrease in titre, by boiling and subsequent dilution of the antigen extract in $1 \%$ Tween $80-$ GBS. Dilution of the antigen preparation also permits detection of possible prozone phenomena which, although not encountered here, have been observed in similar latex tests (Bloomfield, Gordon \& Elmdorf, i963).

Although not yet tried, a latex test might also be used to detect furunculosis carriers. Such fish, which may exceed $10 \%$ of a population, show no overt sign of the disease yet harbour the bacterium in their tissues and when stressed may succumb, subsequently infecting other fish. At present no method exists for their detection, for cultural methods are too insensitive and the fluorescent antibody test insufficiently developed. It is of considerable interest, therefore, that both Newman, Stevens \& Gaafar (1970) and Severin (1972) found the latex test to be more sensitive than culture of cerebrospinal fluid for the diagnosis of human bacterial meningitis.

I believe that the present method of antigen extraction could be improved and the sensitivity of the test itself be increased, perhaps by using a tube method. This might permit the detection of furunculosis carriers.

\section{REFERENCES}

Bloomfield, N., Gordon, M. A. \& Elmdorf, D. F., Jun. (1963). Detection of Cryptococcus neoformans antigen in body fluids by latex particle agglutination. Proceedings of the Society of Experimental and Biological Medicine II4, 64-67.

McCarthy, D. H. \& Rawle, C. T. (1975). The rapid serological diagnosis of fish furunculosis caused by 'smooth' and 'rough' strains of Aeromonas salmonicida. Journal of General Microbiology 86, 185-187.

Newman, R. B., Stevens, R. W. \& GaAfar, H. A. (1970). Latex agglutination test for the diagnosis of Haemophilus influenzae meningitis. Journal of Laboratory and Clinical Medicine 76, 107-II3.

SEverin, W. J. P. (1972). Latex agglutination in the diagnosis of meningococcal meningitis. Journal of Clinical Pathology 25, 1079-1082.

WestPhal, O., LÜderitz, O. \& Bister, F. (1952). Über die Extraktion von Bakterien mit Phenol/Wasser. Zeitschrift für Naturforschung $7 \mathrm{~B}, \mathrm{I} 48-155$. 